\title{
Spatial variability of cyanobacterial community composition in Sanya Bay as determined by DGGE fingerprinting and multivariate analysis
}

\author{
LING Juan ${ }^{1,2,3,4}$, ZHANG YanYing ${ }^{1,3}$, DONG JunDe ${ }^{1,3^{*}}$, WANG YouShao ${ }^{2}$, HUANG Hui ${ }^{1,3}$, \\ CHEN Lei ${ }^{1,3,4}$, HUANG XiaoFang ${ }^{1,3,4}$, LONG LiJuan ${ }^{1} \&$ ZHANG Si ${ }^{1}$ \\ ${ }^{1}$ Key Laboratory of Marine Bio-resourses Sustainable Utilization, South China Sea Institute of Oceanology, Chinese Academy of Sciences, \\ Guangzhou 510301, China; \\ ${ }^{2}$ State Key Laboratory of Tropical Oceanography, South China Sea Institute of Oceanology, Chinese Academy of Sciences, \\ Guangzhou 510301, China; \\ ${ }^{3}$ National Experiment Station of Tropical Marine Biology, Chinese Academy of Sciences, Sanya 572000, China; \\ ${ }^{4}$ Graduate University of Chinese Academy of Sciences, Beijing 100049, China
}

Received April 25, 2012; accepted June 7, 2012; published online September 6, 2012

\begin{abstract}
The cyanobacterial communities in the surface and bottom waters of Sanya Bay were investigated on April 24 and 25, 2010. Flow cytometry showed that the total cyanobacterial abundance in the surface and bottom layers ranged from $0.7 \times 10^{4}$ to $2.38 \times 10^{4}$ cells $\mathrm{mL}^{-1}$ and from $1 \times 10^{4}$ to $1.8 \times 10^{4}$ cells $\mathrm{mL}^{-1}$, respectively. Cyanobacterial diversity was analyzed using a molecular fingerprinting technique called denaturing gradient gel electrophoresis (DGGE), followed by DNA sequencing. The results were then interpreted through multivariate statistical analysis. Differences in the compositions of cyanobacterial communities were observed in the surface and bottom waters at the same station, with some bands obtained from both the surface and bottom layers, whereas some bands were present only in one layer. The predominant cyanobacterial species of the excised DGGE bands were related to Synechococcus or Synechococcus-like species (56.2\%). Other phylogenetic groups identified included Chroococcidiopsis (6.3\%), Cyanobium (6.3\%) and some unclassified cyanobacteria (31.2\%). A redundancy analysis (RDA) was conducted to reveal the relationships between the cyanobacterial community composition and environmental factors. Analysis results showed that the spatial variations in the cyanobacterial community composition in surface waters was significantly related to chlorophyll $a(\mathrm{Chl} a)$, the biochemical oxygen demand (BOD), nitrate and phosphate $(P<0.05)$. Meanwhile, the spatial variations in the bottom waters was significantly affected by nitrate, nitrite, and phosphate $(P<0.05)$. Environmental parameters could explain $99.3 \%$ and $58.3 \%$ of the variations in the surface and bottom layers, respectively.
\end{abstract}

cyanobacterial community composition, PCR-DGGE, Synechococcus, redundancy analysis

Citation: Ling J, Zhang Y Y, Dong J D, et al. Spatial variability of cyanobacterial community composition in Sanya Bay as determined by DGGE fingerprinting and multivariate analysis. Chin Sci Bull, 2013, 58: 1019-1027, doi: 10.1007/s11434-012-5424-4

Cyanobacteria occupy a wide range of environmental niches in tropical marine regions and are the most diverse photosynthetic bacteria [1]. These organisms are considered to be major $\mathrm{N}_{2}$-fixation microorganisms in the open ocean and are essential components of the microbial food web [2,3]. The $\mathrm{N}_{2}$ fixation of diazotrophic picocyanobacteria is estimated to provide a global rate of $100 \mathrm{Tg} \mathrm{a}^{-1}$ in warm oligotrophic

*Corresponding author (email: dongjunde@vip.163.com) waters [4]. The $\mathrm{N}_{2}$-fixation process is also important in providing the nutrient flux that support carbon loss in the deep ocean and limit the concentration of the greenhouse gas, carbon dioxide. Cyanobacteria (e.g. Lyngbya sp.) are also the source of bioactive compounds [5] and are capable of degrading organic pollutants, such as polycyclic aromatic hydrocarbons and xenobiotics [6].

Sanya Bay, a typical tropical bay, is located in China's Hainan Island. It consists of several tropical ecosystems 
such as coral reefs, mangroves, and seagrass beds. Previous investigations suggested Sanya Bay to be a warm and oligotrophic bay, with nitrogen as the main nutrient that limits primary production [7-9]. Cyanobacteria in Sanya Bay have been proven to be a major component of total phytoplankton biomass and productivity [10]. However, systematic investigations of the cyanobacterial population are rarely conducted, and no genetic information is available. Early studies on cyanobacterial identification in Sanya Bay relied primarily on microscopic analysis and were based on morphological characteristics [11]. These conventional methods for cyanobacterial studies were time-consuming and labor intensive, and may disregard some important picocyanobacterial species because of certain limitations. As a result, polymerase chain reaction-denaturing gradient gel electrophoresis (PCR-DGGE) and DNA sequence analysis were used in the present study to survey the structure of the cyanobacterial communities using natural samples collected from Sanya Bay [12]. In addition, direct multivariate analyses such as redundancy analysis (RDA) were used to study the species-environmental relationships. High-resolution DNA fingerprinting combined with multivariate analysis has been used to investigate the variability in the marine microbial community structure in aquatic ecosystems [13].

This study provided a detailed understanding of cyanobacterial communities in the surface and bottom waters of Sanya Bay. The overall objectives were as follows: (1) to investigate the cyanobacterial community structure and the dominant cyanobacterial species; (2) to assess the spatial variability of cyanobacterial community composition in surface and bottom waters; and (3) to determine the variations of cyanobacteria in relation to physicochemical parameters of the waters. The results of this study will help to facilitate further investigation of the cyanobacterial community structure in Sanya Bay.

\section{Materials and methods}

\subsection{Study area and sampling methods}

Sanya Bay lies in the southernmost part $\left(109^{\circ} 20^{\prime}-109^{\circ} 30^{\prime} \mathrm{E}\right.$, $18^{\circ} 11^{\prime}-18^{\circ} 18^{\prime} \mathrm{N}$ ) of Hainan Island in China [13]. It is a typical tropical Bay with a water surface area of $120 \mathrm{~km}^{2}$ and an average depth of $16 \mathrm{~m}$. This bay consists of Dongmao, Ximao, and Luhuitou Islands, which are located at its mouth [13]. Except for Station 4 (26 m) and Station 9 (28 m), the rest of the sampling stations are located at depths of $<20 \mathrm{~m}$. Water samples were collected using $5 \mathrm{~L}$ Niskin bottles from the surface and the bottom of the 12 stations in Sanya Bay during surveys held on 24 and 25 April, 2010 (Figure 1). Water quality parameters such as temperature (Temp), salinity $(S)$ and dissolved oxygen (DO) were measured in situ using a water quality Monitoring system (Hydrolab Corporation, USA). Nutrients such as nitrate $\left(\mathrm{NO}_{3}-\mathrm{N} / \mu \mathrm{mol} \mathrm{L}^{-1}\right)$, nitrite $\left(\mathrm{NO}_{2}-\mathrm{N} / \mu \mathrm{mol} \mathrm{L}{ }^{-1}\right)$ and, silicate $\left(\mathrm{SiO}_{4}-\mathrm{Si} / \mu \mathrm{mol} \mathrm{L}{ }^{-1}\right)$

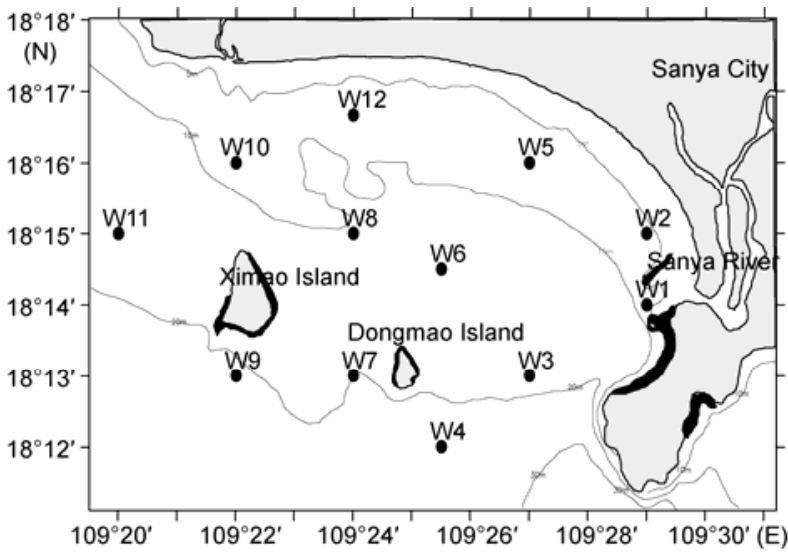

Figure 1 Sampling stations in the coral reefs area of Sanya Bay.

were analyzed using a SKALAR autoanalyzer (Skalar, Breda, The Netherlands). In addition, ammonium $\left(\mathrm{NH}_{4}-\mathrm{N} /\right.$ $\left.\mu \mathrm{mol} \mathrm{L}{ }^{-1}\right)$ and phosphorus $\left(\mathrm{PO}_{4}-\mathrm{P} / \mu \mathrm{mol} \mathrm{L}{ }^{-1}\right)$ were analyzed through the oxidization by hypobromite and molybdophosphoric blue, respectively, which were monitored used an Ultraviolet (UV) 1601 spectrophotometer (Shimadzu Corporation, Japan) [14]. Cyanobacterial abundance was analyzed according to the methods described in "The Specialties for Marine Monitoring" [14]. One liter of seawater samples was filtered through $0.22 \mu \mathrm{m}$ pore size cellulose acetate membrane filters (Millipore, USA). After filtration, the membranes were immediately frozen in liquid nitrogen and then stored at $-20^{\circ} \mathrm{C}$ in preparation for DNA extraction in the laboratory.

\subsection{Physicochemical parameter analyses}

Analysis of the physicochemical parameters was conducted according to methods prescribed by Huang et al. [15], Zhou et al. [16], and the Specification for Oceanography Survey [14].

\subsection{DNA extraction, PCR amplification and DGGE}

Community DNA extraction was performed according to the method prescribed by Bostrom et al. [17]. The 16S rDNA fragments were first amplified using the primers CYA359F and 23S30R [18]. PCR amplifications were performed using a PTC-2000 thermal cycler (Bio-Rad, USA). This thermal cycling was conducted according to the method used by Nübel et al. [19]. The second PCR reaction was performed using the forward primer $\mathrm{CYA} 359 \mathrm{~F}$ and an equimolar mixture of the reverse primers CYA781R (a) and (b) [19]. The reverse primer (a) amplifies the filamentous cyanobacteria, whereas the reverse primer (b) targets the unicellular cyanobacteria. A 40 bp GC clamp (CGCCCGCCGCGCGCGGCGGGCGGGGCGGGGGCACGGGGGG) was added to primer $359 \mathrm{~F}\left(5^{\prime}\right)$ to enhance the separation of the DNA bands in the DGGE gel [20]. Each PCR reaction was performed in triplicate to reduce possible intersample 
PCR variations. The PCR products were then pooled and purified prior to loading on the DGGE gel. Equal amounts of the PCR products ( $40 \mu \mathrm{L}$ PCR product with $7 \mu \mathrm{L}$ loading dye) from the different stations were loaded onto an acrylamide gel (6\% acrylamide, $1 \mathrm{~mm}$ thick). DGGE was performed using the INGENYphor U-2 system (Ingeny International BV, The Netherlands). The $100 \%$ denaturing solution consisted of $7 \mathrm{~mol} \mathrm{~L}^{-1}$ urea and $40 \%$ formamide $(\mathrm{v} / \mathrm{v})$. Optimal separation of cyanobacterial DNA in the samples was achieved using a $45 \%-70 \%$ denaturing gradient. DGGE was performed at $60^{\circ} \mathrm{C}$ for $17 \mathrm{~h}$ at a constant voltage of $100 \mathrm{~V}$. After electrophoresis, the DGGE gels were stained with ethidium bromide and visualized under UV light using an AlphaImager imaging system (Alpha Innotech, USA). Individual DGGE bands of interest were excised and then reamplified with CYA359F- CYA781R (a) and (b) under previously described reaction conditions [19]. The PCR products were again loaded onto a DGGE gel to confirm the band positions. Products of the same mobility were purified, ligated into a pMD18-T cloning vector, and subsequently transformed into Escherichia coli DH5a according to the manufacturer's instructions (Takara Shuzo Co, Ltd, Otsu, Japan). Positive recombinants were then submitted for sequencing with an M13 primer on an ABI3730 DNA Sequencer (USA) at the Shanghai Invitrogen Biotech Co., Ltd. The obtained sequences were analyzed against sequences in the Ribosomal Database Project (RDP) using the Classier tool, and against GenBank sequences using the Basic Local Alignment Search Tool (BLAST) program [21,22]. Phylogenetic trees of $16 \mathrm{~S}$ rDNA partial sequences were generated using the neighbor-joining algorithms in Mega IV software [23]. The evolutionary distances were computed using the maximum composite likelihood method [24] and expressed as the number of base substitutions per site. The level of support for the phylogenies derived from the neighbor-joining analysis was determined using 1000 bootstrap replicates [25].

\subsection{Data analysis}

All samples were collected in triplicate, and data were presented as the mean values. The DGGE fingerprint results for the surface waters and bottom waters communities were analyzed according to the method prescribed by Zhang et al. [26]. The band positions and intensities were both considered. Canoco for Windows 4.5 (Wageningen, The Netherlands) was used to determine the relationships between community compositions and physicochemical parameters. First, detrended correspondence analysis was performed to decide between a linear and a unimodal response model for the multivariate analysis. Given that the gradient lengths of the first axis were 2.269 and 4.388 for the surface and bottom layers, respectively, RDA ordination was used to investigate the spatial variations and the environmental factors [27-29].

\section{Results}

\subsection{Physicochemical parameters of the ocean water}

The basic physicochemical parameters investigated are summarized in Table 1. Salinity in the bottom layer station $(34.30 \%-34.41 \%$ o $)$ was higher than that in the surface layer $(34.16 \%$ - $34.37 \%$ o $)$ at the same station. The lowest DO concentration in the surface waters $\left(6.96 \mathrm{mg} \mathrm{L}^{-1}\right)$ and bottom waters $\left(6.90 \mathrm{mg} \mathrm{L}^{-1}\right)$ appeared at Station $\mathrm{W} 1$, where Sanya River flows into the bay. Compared with other stations, this station also had the highest chlorophyll $a$ and nutrient concentrations (phosphate, silicate, nitrite, nitrate and ammonium). The Chl $a$ concentration in the surface waters was $2.93 \mu \mathrm{g} \mathrm{L}^{-1}$, which was almost 15.4 times that in Station W10. The mean Chla concentration gradually decreased from the coastal stations to off-shore stations. Flow cytometry showed that total cyanobacterial abundance in the surface and bottom waters ranged from $0.7 \times 10^{4}$ to $2.38 \times 10^{4}$ cells $\mathrm{mL}^{-1}$ and from $1 \times 10^{4}$ to $1.8 \times 10^{4}$ cells $\mathrm{mL}^{-1}$, respectively.

\subsection{Cyanobacterial DGGE profiles}

The DGGE-bands were labelled " $C$ ", followed by the specific number assigned to a specific $16 \mathrm{~S}$ rDNA sequence obtained from the cyanobacterial communities (Figures 2-4). The sequence analysis results of the excised DGGE bands are summarized in Table 2. The nucleotide sequence accession numbers obtained in this study are available in the GenBank database under the accession numbers JF914949 to JF914964.

Most of the phylotypes (56.3\%) were identified as Synechococcus or Synechococcus-like species. The rest of the phylogenetic groups identified included Chroococcidiopsis (6.3\%), Cyanobium (6.3\%) and some unclassified cyanobacteria $(31.2 \%)$. The percentage similarity with the clone and its closest blast hits ranged from $93 \%$ to $99 \%$, respectively. Sequences obtained from Sanya Bay were similar to those from other marine environments such as the oligotrophic Kuroshio Current near the outer edge of the East China Sea, the water column in the Red Sea, seawater of the East China Sea, and the South Atlantic Subtropical Gyre and so on.

\subsection{Community composition in relation to water phys- icochemical properties}

Table 3 and Figure 3 show that the first and second RDA axes account for $98.6 \%$ to $99.2 \%$ of the variations in the cyanobacterial community composition in surface waters. Meanwhile, for the bottom waters, $49.1 \%$ and $7.5 \%$ of the variations in the composition could be explained by the first two canonical axes, respectively. The significant environmental variables could explain $99.3 \%$ and $58.3 \%$ of the structural variations in the surface layer and the bottom 
Table 1 Physicochemical parameters of the surface and bottom samples of Sanya Bay (values are given as mean, $n=3$ )

\begin{tabular}{|c|c|c|c|c|c|c|c|c|c|c|c|c|c|c|c|}
\hline Stations & $\begin{array}{l}\text { Temp. } \\
\left({ }^{\circ} \mathrm{C}\right)\end{array}$ & $\begin{array}{c}S \\
(\% o)\end{array}$ & $\mathrm{pH}$ & $\begin{array}{c}\text { DO } \\
\left(\mathrm{mg} \mathrm{L}^{-1}\right)\end{array}$ & $\begin{array}{c}\text { Chla } \\
\left(\mu \mathrm{g} \mathrm{L}^{-1}\right)\end{array}$ & $\begin{array}{c}\mathrm{COD} \\
\left(\mathrm{mg} \mathrm{L}^{-1}\right)\end{array}$ & $\begin{array}{c}\mathrm{BOD} \\
\left(\mathrm{mg} \mathrm{L}^{-1}\right)\end{array}$ & $\begin{array}{c}\mathrm{DIC} \\
\left(\mathrm{mg} \mathrm{L}^{-1}\right)\end{array}$ & $\begin{array}{c}\text { DOC } \\
\left(\mathrm{mg} \mathrm{L}^{-1}\right)\end{array}$ & $\begin{array}{c}\mathrm{SiO}_{4}-\mathrm{Si} \\
\left(\mathrm{mg} \mathrm{L}^{-1}\right)\end{array}$ & $\begin{array}{c}\mathrm{PO}_{4}-\mathrm{P} \\
\left(\mathrm{mg} \mathrm{L}^{-1}\right)\end{array}$ & $\begin{array}{r}\mathrm{NO}_{2}-\mathrm{N} \\
\left(\mathrm{mg} \mathrm{L}^{-1}\right)\end{array}$ & $\begin{array}{r}\mathrm{NO}_{3}-\mathrm{N} \\
\left(\mathrm{mg} \mathrm{L}^{-1}\right)\end{array}$ & $\begin{array}{c}\mathrm{NH}_{4}-\mathrm{N} \\
\left(\mathrm{mg} \mathrm{L}^{-1}\right)\left(\mathrm{ce}^{2}\right.\end{array}$ & $\begin{array}{c}\mathrm{CA} \\
\text { ells } \mathrm{mL}^{-1} \text { ) }\end{array}$ \\
\hline WS1 & 26.32 & 34.16 & 8.12 & 6.96 & 2.93 & 0.98 & 0.52 & 27.77 & 1.291 & 0.105 & 0.009 & 0.004 & 0.024 & 0.017 & 2.37 \\
\hline WS2 & 26.39 & 34.34 & 8.13 & 7.25 & 1.47 & 1.13 & 0.50 & 27.68 & 2.196 & 0.098 & 0.006 & 0.003 & 0.010 & 0.014 & 2.06 \\
\hline WS3 & 26.45 & 34.32 & 8.06 & 7.06 & 0.41 & 0.33 & 0.22 & 28.20 & 1.187 & 0.099 & 0.003 & 0.002 & 0.006 & 0.014 & 0.88 \\
\hline WS4 & 26.47 & 34.37 & 8.11 & 7.11 & 0.42 & 0.65 & 0.20 & 27.85 & 1.076 & 0.086 & 0.003 & 0.002 & 0.009 & 0.016 & 0.88 \\
\hline WS5 & 26.84 & 34.24 & 8.15 & 7.32 & 0.30 & 0.73 & 0.07 & 27.57 & 1.005 & 0.091 & 0.004 & 0.002 & 0.005 & 0.016 & 0.70 \\
\hline WS6 & 26.30 & 34.36 & 8.08 & 7.15 & 0.56 & 0.36 & 0.28 & 28.10 & 1.060 & 0.114 & 0.004 & 0.001 & 0.006 & 0.014 & 1.66 \\
\hline WS7 & 26.37 & 34.35 & 8.06 & 7.11 & 0.67 & 0.91 & 0.08 & 28.21 & 0.822 & 0.098 & 0.003 & 0.002 & 0.007 & 0.013 & 1.62 \\
\hline WS8 & 26.59 & 34.32 & 8.12 & 7.11 & 0.84 & 0.22 & 0.10 & 27.77 & 1.027 & 0.090 & 0.003 & 0.002 & 0.007 & 0.013 & 1.49 \\
\hline WS9 & 26.40 & 34.33 & 8.06 & 7.13 & 1.28 & 0.62 & 0.01 & 28.20 & 0.701 & 0.099 & 0.005 & 0.001 & 0.006 & 0.016 & 2.23 \\
\hline WS10 & 26.78 & 34.28 & 8.13 & 7.16 & 0.19 & 0.29 & 0.16 & 27.74 & 1.159 & 0.094 & 0.004 & 0.003 & 0.009 & 0.014 & 0.80 \\
\hline WS11 & 26.69 & 34.23 & 8.12 & 7.10 & 0.50 & 0.29 & 0.10 & 27.71 & 0.773 & 0.088 & 0.003 & 0.001 & 0.006 & 0.015 & 1.32 \\
\hline WS12 & 27.38 & 34.19 & 8.11 & 7.21 & 0.65 & 0.87 & 0.07 & 27.84 & 0.740 & 0.105 & 0.004 & 0.002 & 0.009 & 0.014 & 1.45 \\
\hline WB1 & 26.20 & 34.30 & 8.11 & 6.90 & 1.17 & 0.84 & 0.08 & 27.84 & 0.602 & 0.103 & 0.006 & 0.003 & 0.014 & 0.018 & 1.81 \\
\hline WB2 & 26.04 & 34.38 & 8.08 & 7.21 & 0.60 & 0.76 & 0.35 & 28.10 & 1.562 & 0.103 & 0.004 & 0.002 & 0.007 & 0.016 & 1.50 \\
\hline WB3 & 26.11 & 34.46 & 8.09 & 7.03 & 1.05 & 0.44 & 0.21 & 28.01 & 1.071 & 0.103 & 0.002 & 0.001 & 0.006 & 0.015 & 0.95 \\
\hline WB4 & 26.10 & 34.32 & 8.13 & 7.10 & 0.42 & 0.76 & 0.08 & 27.68 & 1.032 & 0.094 & 0.002 & 0.002 & 0.008 & 0.014 & 1.04 \\
\hline WB5 & 26.50 & 34.35 & 8.10 & 7.36 & 1.25 & 0.87 & 0.03 & 27.93 & 0.999 & 0.086 & 0.002 & 0.002 & 0.007 & 0.015 & 1.00 \\
\hline WB6 & 26.21 & 34.41 & 8.13 & 7.11 & 0.70 & 0.33 & 0.06 & 27.68 & 0.817 & 0.097 & 0.002 & 0.001 & 0.006 & 0.017 & 1.30 \\
\hline WB7 & 26.07 & 34.34 & 8.07 & 7.26 & 0.77 & 0.80 & 0.19 & 28.18 & 1.098 & 0.086 & 0.002 & 0.001 & 0.007 & 0.014 & 1.09 \\
\hline WB8 & 26.42 & 34.35 & 8.13 & 7.11 & 0.22 & 0.33 & 0.16 & 27.68 & 0.971 & 0.101 & 0.002 & 0.002 & 0.008 & 0.015 & 1.61 \\
\hline WB9 & 26.26 & 34.36 & 8.08 & 7.20 & 1.09 & 0.65 & 1.06 & 28.10 & 1.032 & 0.101 & 0.003 & 0.001 & 0.007 & 0.018 & 1.23 \\
\hline WB10 & 26.46 & 34.33 & 8.13 & 7.13 & 0.55 & 7.64 & 0.32 & 27.68 & 1.021 & 0.084 & 0.003 & 0.001 & 0.006 & 0.013 & 1.32 \\
\hline WB11 & 26.40 & 34.34 & 8.11 & 7.31 & 0.59 & 0.55 & 0.02 & 27.84 & 0.701 & 0.097 & 0.002 & 0.001 & 0.005 & 0.013 & 1.40 \\
\hline WB12 & 26.55 & 34.33 & 8.12 & 7.43 & 0.85 & 0.47 & 0.16 & 27.77 & 0.833 & 0.103 & 0.003 & 0.001 & 0.006 & 0.016 & 1.31 \\
\hline
\end{tabular}

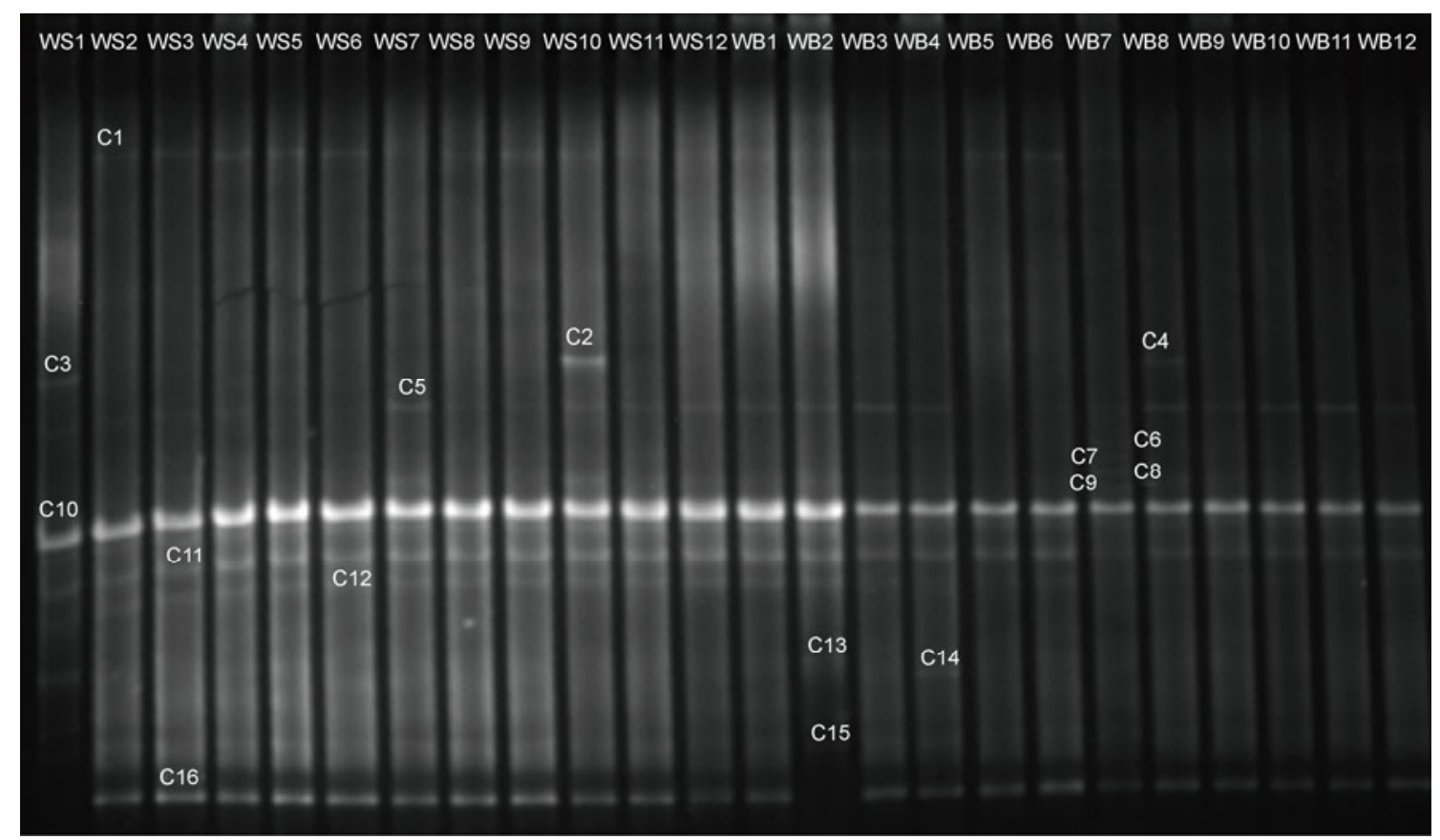

Figure 2 Denaturing gradient gel electrophoresis (DGGE) patterns of the amplified cyanobacterial 16S rDNA gene fragments of the bacterial communities at the sampling sites of Sanya Bay, and of the sequences of the labeled DGGE bands that were excised and sequenced. 

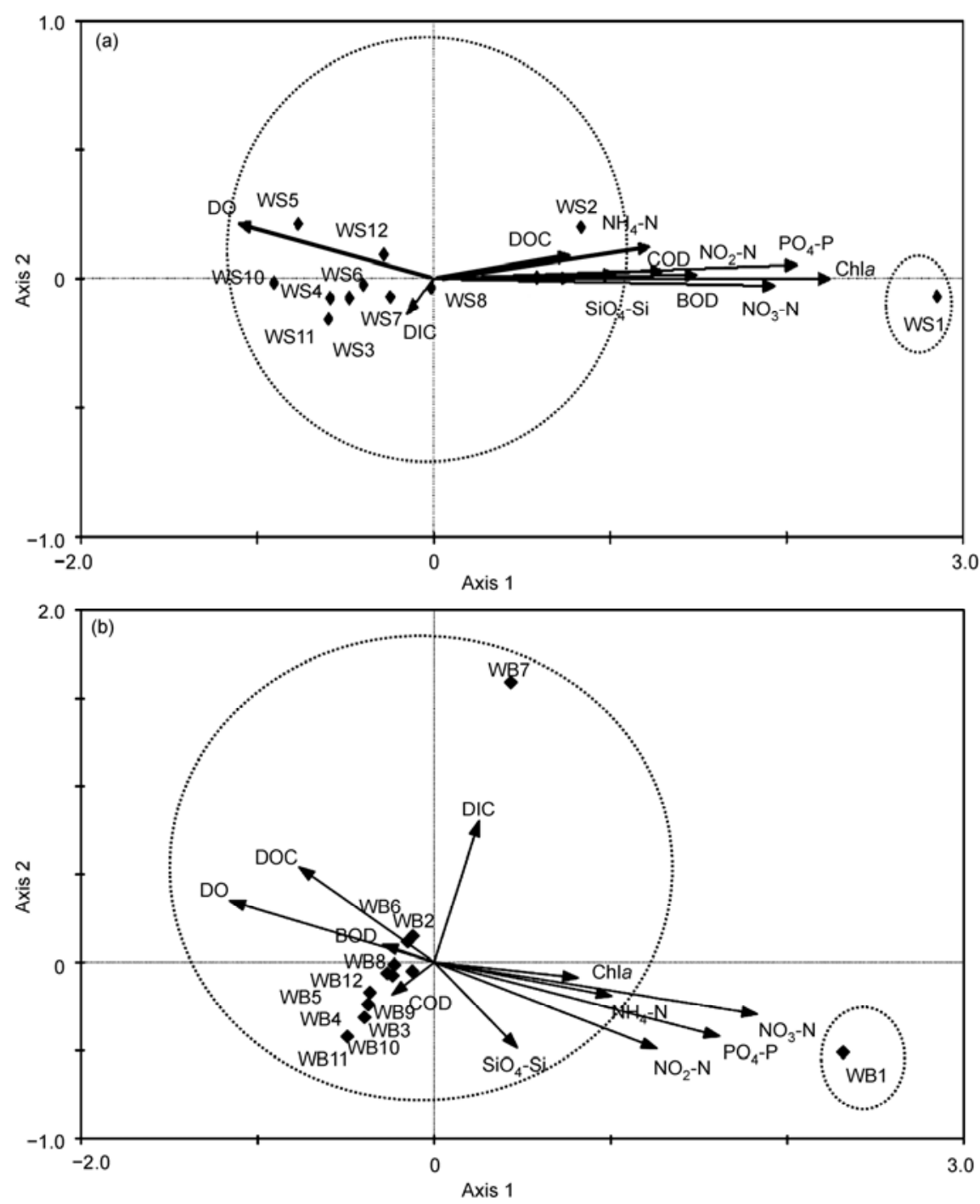

Figure 3 Redundancy analysis (RDA) ordination biplots of DGGE band data for (a) the surface cyanobacterial communities and (b) the bottom cyanobacterial communities (the samples are indicated by the sample site location code, whereas the environmental variables are represented by arrows). The length of each arrow is correlated with the degree of relationship between the response variables.

Table 2 Summary of closest relatives to the excised and sequenced bands derived from the DGGE profile

\begin{tabular}{|c|c|c|c|c|}
\hline $\begin{array}{l}\text { Band } \\
\text { No. }\end{array}$ & $\begin{array}{c}\text { Accession } \\
\text { No. }\end{array}$ & Database match with acession No. in parentheses & Origin & $\begin{array}{c}\text { Identity } \\
(\%)\end{array}$ \\
\hline $\mathrm{C} 1$ & JF914949 & Synechococcus sp. KORDI-49 (FJ497747) & Seawater of the East China Sea & 97 \\
\hline $\mathrm{C} 2$ & JF914950 & Uncultured cyanobacterium Bac18 (HM485317) & Surface seawater $(5 \mathrm{~m})$ from North Western Mediterranean Sea & 99 \\
\hline $\mathrm{C} 3$ & JF914951 & Synechococcus sp. MBIC10089 (AB058226) & Japan sea halotolerant & 98 \\
\hline $\mathrm{C} 4$ & JF914952 & Uncultured cyanobacterium A8W_30 (HM057799) & Ocean water from the Yellow Sea & 99 \\
\hline $\mathrm{C} 5$ & JF914953 & Synechococcus sp. KORDI-56 (FJ497734) & Seawater of the East Sea & 99 \\
\hline C6 & JF914954 & Uncultured Synechococcus sp. 031806\#44 (FJ903279) & Oligotroph Kuroshio Current near the outer edge of East China Sea & 99 \\
\hline $\mathrm{C} 7$ & JF914955 & Synechococcus sp. KORDI-15 (FJ497743) & Seawater of the East Sea & 99 \\
\hline $\mathrm{C} 8$ & JF914956 & Uncultured Synechococcus sp. JL-SCS-L51 (AY664001) & South China Sea & 99 \\
\hline C9 & JF914957 & Chroococcidiopsis sp. BB96.1 (AJ344555) & South Africa & 93 \\
\hline $\mathrm{C} 10$ & JF914958 & Synechococcus sp. RS9920 (AY172830) & Water column in the Red Sea & 99 \\
\hline C11 & JF914959 & Uncultured cyanobacterium Souza16sRcya18q (DQ363186) & Yucatan channel & 99 \\
\hline $\mathrm{C} 12$ & JF914960 & Uncultured cyanobacterium ARTE9_416 (GU230462) & Coastal water & 99 \\
\hline $\mathrm{C} 13$ & JF914961 & Synechococcus sp. KORDI-71 (FJ497742) & Seawater of the East China Sea & 99 \\
\hline C14 & JF914962 & Uncultured Synechococcus sp. clone 031606\#40 (FJ903235) & Oligotrophic region of the Kuroshio Current & 99 \\
\hline $\mathrm{C} 15$ & JF914963 & Cyanobium sp. JJ22K (AM710364) & Mesotrophic and eutrophic freshwater reservoirs & 99 \\
\hline $\mathrm{C} 16$ & JF914964 & Uncultured cyanobacterium Bac18 (HM485317) & Surface seawater from North Western Mediterranean Sea & 99 \\
\hline
\end{tabular}




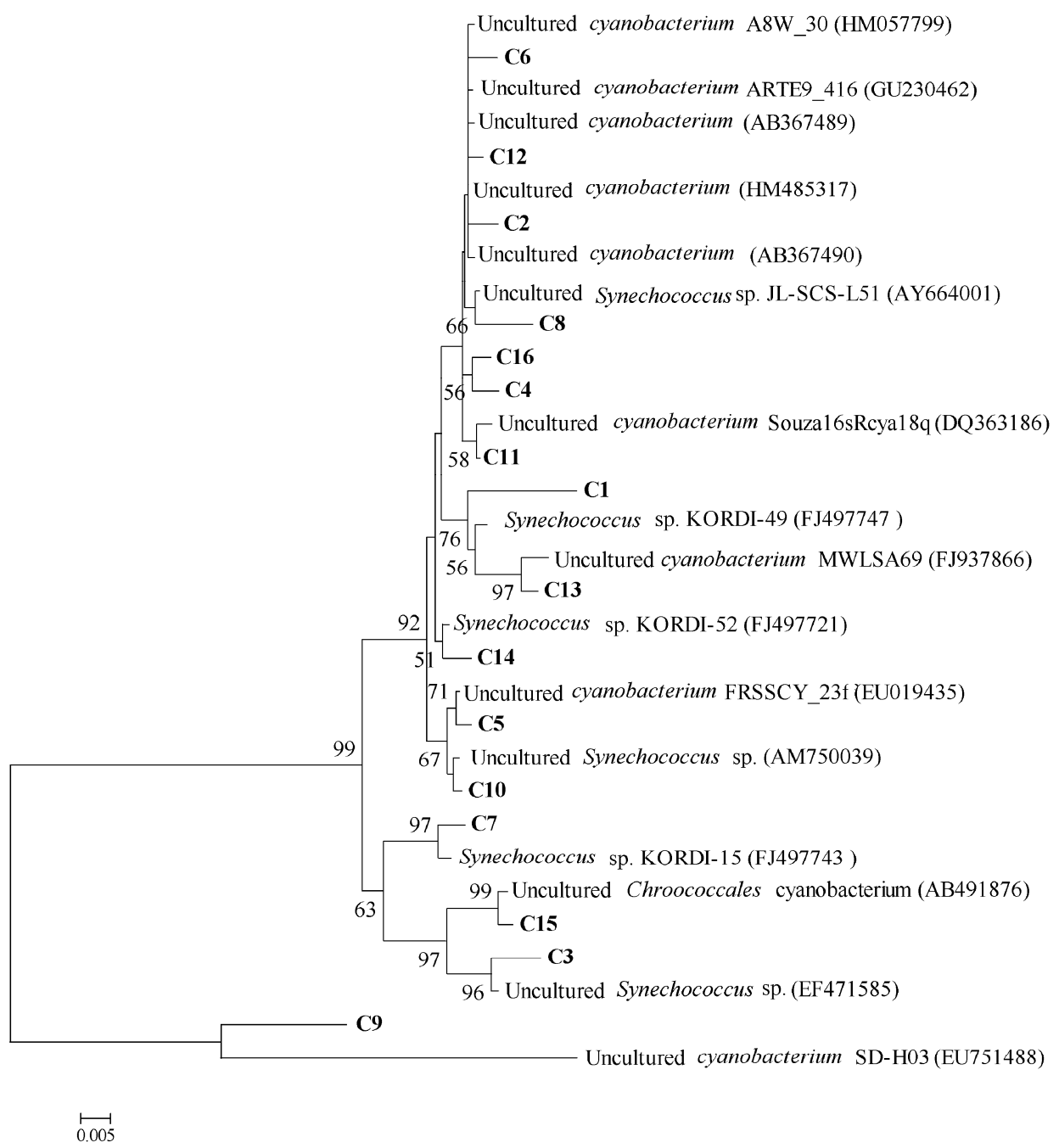

Figure 4 Unrooted phylogenetic tree based on partial 16S rDNA sequences that represent the DGGE bands indicated in Figure 2. Bootstrap analysis was based on 1000 replicates. Bootstrap values from distance analyses are shown. Bootstrap values below 50\% are not shown. The scale indicates 5\% sequence divergence.

Table 3 Redundancy analysis results of surface and bottom bacterial DGGE profiles ${ }^{\text {a) }}$

\begin{tabular}{cccccc}
\hline Axis & Eigen value & $\begin{array}{c}\text { Species-environment } \\
\text { correlation }\end{array}$ & $\begin{array}{c}\text { Cumulative } \% \\
\text { variations of species }\end{array}$ & $\begin{array}{c}\text { Cumulative \% variations } \\
\text { of species-environment }\end{array}$ & $\begin{array}{c}\text { Sum of all canocial } \\
\text { eigen value }\end{array}$ \\
\hline $\begin{array}{c}\text { Surface cyanobacterial } \\
\text { communities }\end{array}$ & & & & & 0.993 \\
Axis 1 & 0.986 & 1 & 98.6 & 99.3 & \\
Axis 2 & 0.006 & 0.72 & 99.2 & 99.9 \\
Axis 3 & 0.001 & 0.624 & 99.2 & 100.0 & \\
Axis 4 & 0.000 & 0.55 & 99.3 & & 0.583 \\
\hline Bottom cyanobacterial & & & & & \\
communities & 0.491 & 0.96 & 49.1 & 97.3 & \\
Axis 1 & 0.075 & 0.618 & 56.6 & 100 & \\
Axis 2 & 0.017 & 0.867 & 58.3 & 0 & \\
Axis 3 & 0.023 & 0.000 & 81.3 & & \\
Axis 4 & & & & \\
\hline
\end{tabular}

a) Monte Carlo significance tests for surface bacterial data: sum of all Eigen values, 1.000 ; significance of first canonical axis, $F$ value $=81.709, P=0.002$; significance of all canonical axes, $F$ value $=234.089, P=0.002$. Monte Carlo significance tests for bacterial data: sum of all Eigen values, 1.000 ; significance of first canonical axis, $F$ value $=8.483, P=0.002$; significance of all canonical axes: $F$ value $=4.233, P=0.002 . F$ and $P$ values were estimated using Monte Carlo permutations. 
layer, respectively. These results indicated that $99.3 \%$ of all variations within cyanobacterial communities in the surface layer were caused by environmental factors, whereas these factors account for only $58.3 \%$ of the variations in the bottom layer communities. The first two axes of the RDA ordination indicated the species-environment relationships as $99.3 \%$ and $99.9 \%$ for the surface layer, and $84.3 \%$ and $97.1 \%$ for and bottom layer. According to the Monte Carlo test, the $P$-value (which indicate the significance) of the first canonical axis and all canonical axes for the surface communities were both 0.002 , respectively, whereas those for the bottom communities were 0.016 and 0.032 , respectively. These results revealed that the environmental variables played vital roles in driving the observed spatial variations in cyanobacterial community composition. Furthermore, the Monte Carlo analysis indicated that Chl $a(P=0.002 ; P<0.01)$, BOD $(P=0.014 ; P<0.05), \mathrm{PO}_{4}-\mathrm{P}(P=0.002 ; P<0.01)$, and $\mathrm{NO}_{3}-\mathrm{N}(P=0.002 ; P<0.01)$ showed a strong correlation with surface cyanobacterial community composition, whereas $\mathrm{NO}_{3}-\mathrm{N}(P=0.001 ; P<0.01), \mathrm{PO}_{4}-\mathrm{P}(P=0.002 ; P<0.01)$, and $\mathrm{NO}_{2}-\mathrm{N}(P=0.026 ; P<0.05)$ significantly affected the spatial variations in the cyanobacterial species composition at the bottom layer. The environmental factors affecting these two layers were different. The cyanobacterial community in Station W1 was remarkably different from those in other stations.

\section{Discussion}

The different cyanobacterial species were not evenly distributed in all stations in the surface and bottom waters (Figure 2). Some bands were detected only in few stations. For instance, band C3 was only detected in the surface layer of Station W1. However, bands C4, C6, C7, C8, and C9 were only detected at the bottom layer of Station W7. Some bands were detected in most of the lanes, such as band $\mathrm{C} 1$, $\mathrm{C} 5, \mathrm{C} 10, \mathrm{C} 11$ and $\mathrm{C} 12$. In particular, band C10 was found in every lane but in varying densities. This distribution may be attributed to differences in nutrient concentrations. The distribution pattern of the surface layer was such that stations located near the Sanya River (e.g. W1 and W2) exhibit higher diversity than the outer stations (e.g. W4, W9, and W11), whereas the bottom layer showed no significant difference.

The predominant band in the DGGE gel was band C10, as indicated by the obtained sequences. The Blast query result showed that the highest similarity sequence for this band is that of Synechococcus sp. RS9920, which has been isolated from the water column in the Red Sea and can use nitrate as a sole $\mathrm{N}$ source for growth [30]. The closest relatives of the sequences C1, C5, C7 and C13 in NCBI Genbank were all from the East China Sea, whereas certain sequences such as C6 and C14 were related to sequences found in the oligotrophic region of the Kuroshio Current.
When the Kuroshio Current passes the Luzon Strait, it forms two branches: one flows into the South China Sea, while the other heads north to the East Sea along the eastern part of Taiwan. The similarities between the sequences obtained from the DGGE gel and those of the East Sea ranged from $97 \%$ to $99 \%$. All related sequences were presumed to be from the Kuroshio Current [31,32]. Station W7 lies between Dongmao Island and Ximao Island, unlike in other stations, tourism and other human activities contributed a lot to the variations in the cyanobacterial community in this station [15]. Sequence C9 only showed 93\% similarity to its closest relatives in the GenBank (Accession No. AJ344555), indicating that this sequence could be representative of a novel cyanobacterial species [33]. Sequence C15 was related to Cyanobium sp. JJ22K, which was isolated from mesotrophic and eutrophic freshwater reservoirs. This species could be found in both freshwater and marine ecosystems, indicating its high adaptability to different environments [34].

Most of the identified sequences were related to Synechococcus or Synechococcus-like species (Table 2). The cyanobacterial communities in both surface and bottom layers of Sanya Bay were apparently dominated by these, which were considered dominant phytoplankton in tropical and subtropical ocean ecosystems. According to Murphy et al. [35], Synechococcus are widely distributed in the different world ocean, with high abundance (ranging from $10^{3}$ to $10^{5}$ cells $\mathrm{mL}^{-1}$ ), particularly in the coastal area [35].

Due to their capability of photosynthesis and nitrogen fixation, they were indispensable components of the biogeochemical cycle such as carbon cycle and nitrogen cycle. Synechococcus and Prochlorococcus are estimated to absorb approximately $1 \times 10^{10} \mathrm{Tg}$ carbon from the atmosphere each year, which is equivalent to two-thirds of the total carbon fixation that occurs in the oceans [36]. Chroococcidiopsis, a unicellular, non-heterocyst-differentiation genus, is a wide-spread cosmopolitan unicellular cyanobacteria found in many extreme environment, such as the airspaces of porous rocks, Antarctic valleys and hot deserts [37]. Another cyanobacterial genus detected in Sanya Bay was $C y$ anobium, which usually constitutes majority component of marine, brackish and freshwater picophytoplankton community

The vast difference in the cyanobacterial community composition of Station W1 could be attributed to the physiochemical property of the water column as a result of the discharge from the Sanya River (Figure 1). RDA results showed that the relationships of the surface and bottom cyanobacterial community composition with environmental factors were different. The significant factors for the spatial variations in surface waters composition were Chla, BOD, nitrate and phosphate, whereas those for the bottom waters were phosphate, nitrate and nitrite. The nitrate and phosphate concentration were significant environmental factors for both surface and bottom layers. This result may be ex- 
plained by the rapid growth of phytoplankton in spring. At this stage, they consumed a considerable amount of phosphate in the ocean waters, thus causing phosphate becomes a limiting factor [38].

RDA ordination results implied that Chl $a$, BOD, nitrate, and phosphate were positively correlated with cyanobacterial species in the surface layer, whereas nitrate, nitrite, and phosphate were positively correlated with the species in the bottom layer. These nutrients can promote cyanobacterial growth. In addition, previous studies in Sanya Bay showed that dissolved inorganic nutrients, particularly phosphate and inorganic nitrogen, were important environmental factors that determine the phytoplankton distribution [38,39]. The limiting factors differ in different ecosystems or within the same ecosystem for different species. Yan et al. [40] found that nitrate, DO, and silicate were the significant factors in the Three Gorges Reservoir. On the other hand, Zeng et al. [41] reported that total nitrogen and ammonium were the determinants of bacterial distribution in eutrophic lakes. Their nutrient addition experiment showed that different species responded differently to the same nutrient concentration. The results showed that the Verrucomicrobia density was the highest in the control group which contained low nutrient concentration and lower in the higher concentration groups, whereas the lowest abundance of Synechococcuslike species was observed in the control group. Hence, further investigation should be conducted to examine the relationship between the seasonal variations in cyanobacterial composition and the physiochemical environmental parameters [40-42].

\section{Conclusions}

In this study, flow cytometry, fingerprinting technique, and multivariate analysis were used to investigate the cyanobacterial community composition and its relationship with the environmental factors in Sanya Bay. The following conclusions have been reached:

(1) Cyanobacterial abundance in surface waters was higher than in bottom waters, ranging from $0.7 \times 10^{4}$ to $2.38 \times 10^{4}$ cells $\mathrm{mL}^{-1}$, and $1 \times 10^{4}$ to $1.8 \times 10^{4}$ cells $\mathrm{mL}^{-1}$, respectively.

(2) The predominant cyanobacterial species obtained from the DGGE gel were identified as Synechococcus or Synechococcus-like species $(56.2 \%)$. Other phylogenetic groups identified include Chroococcidiopsis (6.3\%), Cyanobium (6.3\%), and some unclassified cyanobacteria $(31.2 \%)$.

(3) RDA ordination results showed that the significant environmental factors for the surface layer were Chla $(P=0.002 ; P<0.01)$, BOD $(P=0.014 ; P<0.05)$, nitrate $(P=$ $0.002 ; P<0.01)$, and phosphate $(P=0.002 ; P<0.01)$, whereas those for the bottom layer were nitrate $(P=0.001 ; P<0.01)$, nitrite $(P=0.026 ; P<0.05)$, and phosphate $(P=0.002 ; P<0.01)$.
These environmental parameters accounted for $99.3 \%$ and $58.3 \%$ of the variations in the surface and bottom layers, respectively.

The authors thank all the staff of Hainan Tropical Marine Biology Research Station of the Chinese Academy of Sciences for providing support with the Sample collecting and data processing. This work was supported by the National Science and Technology Supporting Program (2009BAB44B03), the National High-tech R\&D Program of China (2012AA092104), the National Natural Science Foundation of China (40776069, 40676091 and 41006069), and the National Basic Research Program of China (2010CB833800), the Knowledge Innovation Program of Chinese Academy of Sciences (KSCX2-EW-G-12), the Sanya Station Database and the Information System of CERN.

1 Hoffman L. Marine cyanobacteria in tropical regions: Diversity and ecology. Eur J Phycol, 1999, 34: 371-379

2 Capone D G. The marine nitrogen cycle. In: Kirchman D L, ed. Microbial Ecology of the Oceans. New York: Wiley, 2000. 455-494

3 Zehr J P. Nitrogen fixation by marine cyanobacteria. Trends Microbiol, 2011, 19: 162-173

4 Capone D G. Marine nitrogen fixation: What's the fuss? Curr Opin Microbiol, 2001, 4: 341-348

5 Yang B, Dong J D, Yang Z H, et al. Chemical constituents of cyanobacteria Lyngbya sp. from South China Sea (In Chinese). J Trop Oceanogr, 2007, 26: 67-69

6 El-Bestawy E A, Abd El-Salam A Z, Mansy H A R. Potential use of environmental cyanobacterial species in bioremediation of lindanecontaminated effluents. Int Biodeterior Biodegrad, 2007, 59: 180192

7 Ke Z X, Huang L M, Tan Y H, et al. Plankton community structure and diversity in coral reefs area of Sanya Bay, Hainan Province, China. Biod Sci, 2011, 19: 696-701

8 Shi Q, Zhao M X, Zhang Q M, et al. Estimate of carbonate production by scleractinian corals at Luhuitou fringing reef, Sanya, China. Chin Sci Bull, 2009, 54: 696-705

9 Zhang Q M, Shi Q, Chen G, et al. Status monitoring and management strategy research of Luhuitou fringing reef of the Sanya reserve. Chin Sci Bull, 2006, 51(Suppl II): 71-77

10 Dong J D, Zhang Y Y, Wang Y S, et al. Spatial and seasonal variations of Cyanobacteria and their nitrogen fixation rates in Sanya Bay, South China Sea. Sci Mar, 2008, 72: 239-251

11 Dong J D, Wang H K, Zhang S, et al. Vertical distribution characteristics of seawater temperature and DIN in Sanya Bay (in Chinese). J Tropic Oceanol, 2002, 21: 40-47

12 Muyzer G, de Waal E C, Uitterlinden A G. Profiling of complex microbial populations by denaturing gradient gel electrophoresis analysis of polymerase chain reaction amplified genes encoding for $16 \mathrm{~S}$ rRNA. Appl Environ Microbiol, 1993, 59: 695-700

13 Kataoka T, Hodoki Y, Koji S, et al. Tempo-spatial patterns of bacterial community composition in the western North Pacific Ocean. J marine Syst, 2009, 77: 197-207

14 General Administration of Quality Supervision, Inspection and Quarantine of the People's Republic of China and China National Stantardization Management Committee. The Specialties for Marine monitoring (GB17378.4-1998, China) (in Chinese). Beijing: Standards Press of China, 1998. 142-162

15 Huang L M, Tan Y H, Song X Y, et al. The status of the ecological environment and a proposed protection strategy in Sanya Bay, Hainan Island, China. Mar Pollut Bull, 2003, 47: 180-186

16 Zhou W, Li T, Cai C H, et al. Spatial and temporal dynamics of phytoplankton and bacterioplankton biomass in Sanya Bay, northern South China Sea. J Environ Sci-China, 2009, 21: 595-603

17 Bostrom K H, Simu K, Hagstrom A, et al. Optimization of DNA extraction for quantitative marine bacterioplankton community analysis. Limnol Oceanogr Meth, 2004, 2: 365-373 
18 Lepère C, Wilmotte A, Meyer B. Molecular diversity of Microcystis strains (Cyanophyceae, Chroococcales) based on 16S rDNA sequences. Syst Geogr Pl, 2000, 70: 275-283

19 Nübel U, Garcia-Pichel F, Muyzer G. PCR primers to amplify $16 \mathrm{~S}$ rRNA genes from cyanobacteria. Appl Environ Microb, 1997, 63: 3327-3332

20 Muyzer G, Smalla K. Application of denaturing gradient gel electrophoresis (DGGE) and temperature gradient gel electrophoresis (TGGE) in microbial ecology. Anton Leeuw Int J G, 1998, 73: 127-141

21 Maidak B L, Cole J R, Parker C T, et al. A new version of the RDP (Ribosomal Database Project). Nucleic Acids Res, 1999, 27: 171-173

22 Altschul S F, Madden T L, Schaeffer A A, et al. Gapped BLAST and PSI-BLAST: A new generation of protein database search programs. Nucleic Acids Res, 1997, 25: 3389-3402

23 Tamura K, Dudley J, Nei M, et al. MEGA4: Molecular evolutionary genetics analysis (MEGA) software version 4.0. Mol Biol Evol, 2007, 24: 1596-1599

24 Tamura K, Nei M, Kumar S. Prospects for inferring very large phylogenies by using the neighbor-joining method. Prolc Natl Acad Sci USA, 2004, 101: 11030-11035

25 Saitou N, Nei M. The neighbor-joining method: A new method for reconstructing phylogenetic trees. Mol Biol Evol, 1987, 4: 406-425

26 Zhang Y Y, Dong J D, Yang Z H, et al. Phylogenetic diversity of nitrogen-fixing bacteria in mangrove sediments assessed by PCRDGGE. Arch Microbiol, 2008, 190: 19-28

27 Zhang J C, Zeng G M, Chen Y N, et al. Effects of physico-chemical parameters on the bacterial and fungal communities during agricultural waste composting. Bioresource Technol, 2011, 102: 29502956

28 Lepš J, Šmilauer P. Multivariate Analysis of Ecological Data Using CANOCO. Cambridge: Cambridge University Press, 2003. 43-75

29 Luan Q S, Sun J, Song S Q, et al. Canonical correspondence analysis of summer phytoplankton community and its environment in the Yangtze River estuary China (in Chinese). J Plant Ecol, 2007, 31: 445-450

30 Fuller N J, Marie D, Partensky F. Clade-specific 16S ribosomal DNA oligonucleotides reveal the predominance of a single marine Synechococcus clade throughout a stratified water column in the Red Sea. Appl Environ Microbiol, 2003, 2430-2443
31 Choi D H, Noh J H. Phylogenetic diversity of Synechococcus strains isolated from the East China Sea and the East Sea. FEMS Microbiol Ecol, 2009, 69: 439-448

32 Liang W D, Yang Y J, Tang T Y, et al. Kuroshio in the Luzon Strait, J Geophys Res, 2008, 113: C08048

33 Jezberova J. Phenotypic diversity and phylogeny of picocyanobacteria in mesotrophic and eutrophic freshwater reservoirs investigated by a cultivation-dependent polyphasic approach. The Dissertation for the Doctoral Degree. Ceske Budejovice: University of South Bohemia, 2006

34 Rohwer F, Breitbart M, Jara J, et al. Diversity of bacteria associated with the Caribbean coral Montastraea franksi. Coral Reefs, 2001, 20: 85-91

35 Murphy L S, Haugen E M. The distribution and abundance of phototrophic ultraplankton in the North Atlantic. Limnol Oceanogr, 1985, 30: 47-58

36 Iturriaga R, Mitchell B G. Chroococcoid cyanobacteria: A significant component in the food web dynamics of the open ocean. Mar Ecol Prog Ser, 1986, 28: 291-297

37 Fewer D, Friedl T, Budel B. Chroococcidiopsis and heterocystdifferentiating cyanobacteria are each other's closest living relatives. Mol Phylogenet Evol, 2002, 23: 82-90

38 Zhang Y Y, Dong J D, Ling J, et al. Phytoplankton distribution and their relationship to environmental variables in Sanya Bay, South China Sea. Sci Mar, 2010, 74: 783-792

39 Yang Z H, Dong J D, Wu M L, et al. Structure characteristics of phytoplankton community at Sanya Bay (in Chinese). J Trop Oceanogr, 2007, 26: 62-66

40 Yan Q Y, Yu Y H, Feng W S, et al. Plankton community composition in Three Gorges Reservoir region revealed by PCR-DGGE and its relationships with environmental factors. J Environ Sci, 2008, 20: $732-738$

41 Zeng J, Yang L Y, Du H W, et al. Bacterioplankton community structure in a eutrophic lake in relation to water chemistry. World $\mathrm{J}$ Microbiol Biotechnol, 2009, 25: 763-772

42 Sipura J, Haukka K, Helminen H, et al. Effect of nutrient enrichment on bacterioplankton biomass and community composition in mesocosms in the Archipelago Sea, northern Baltic. J Plankton Res, 2005, 27: $1261-1272$

Open Access This article is distributed under the terms of the Creative Commons Attribution License which permits any use, distribution, and reproduction in any medium, provided the original author(s) and source are credited. 